\title{
Alefacept (anti-CD2) causes a selective reduction in circulating effector memory $T$ cells (Tem) and relative preservation of central memory $T$ cells $(\mathrm{Tcm})$ in psoriasis
}

Francesca Chamian, Shao-Lee Lin, Edmund Lee, Toyoko Kikuchi, Patricia Gilleaudeau, Mary Sullivan-Whalen, Irma Cardinale, Artemis Khatcherian, Inna Novitskaya, Knut M Wittkowski, James G Krueger* and Michelle A Lowes

Address: Laboratory for Investigative Dermatology, The Rockefeller University, New York, USA

Email: Francesca Chamian - mfnchamian@msn.com; Shao-Lee Lin - shaol@amgen.com; Edmund Lee - elee96@yahoo.com; Toyoko Kikuchi - kikuchi@rockefeller.edu; Patricia Gilleaudeau - gilleap@ rockefeller.edu; Mary Sullivan-Whalen - whalems@rockefeller.edu; Irma Cardinale - cardini@rockefeller.edu; Artemis Khatcherian - khatcha@ rockefeller.edu; Inna Novitskaya - novitsi@ rockefeller.edu; Knut M Wittkowski - kmw@rockefeller.edu; James G Krueger* - jgk@rockefeller.edu; Michelle A Lowes - lowesm@rockefeller.edu

* Corresponding author

Published: 7 June 2007

Journal of Translational Medicine 2007, 5:27 doi:10.1 186/1479-5876-5-27
Received: 28 February 2007

Accepted: 7 June 2007

This article is available from: http://www.translational-medicine.com/content/5/I/27

(C) 2007 Chamian et al; licensee BioMed Central Ltd.

This is an Open Access article distributed under the terms of the Creative Commons Attribution License (http://creativecommons.org/licenses/by/2.0), which permits unrestricted use, distribution, and reproduction in any medium, provided the original work is properly cited.

\begin{abstract}
Background: Alefacept (anti-CD2) biological therapy selectively targets effector memory $T$ cells (Tem) in psoriasis vulgaris, a model Type I autoimmune disease.

Methods: Circulating leukocytes were phenotyped in patients receiving alefacept for moderate to severe psoriasis.

Results: In all patients, this treatment caused a preferential decrease in effector memory $T$ cells (CCR7- CD45RA-) (mean 63\% reduction) for both $\mathrm{CD}^{+}$and $\mathrm{CD} 8^{+} \mathrm{Tem}$, while central memory $\mathrm{T}$ cells $(T \mathrm{~cm})\left(C C R 7^{+} \mathrm{CD} 45 \mathrm{RA}-\right)$ were less affected, and naïve $T$ cells $\left(C C R 7^{+} \mathrm{CD} 45 R \mathrm{~A}^{+}\right)$were relatively spared. Circulating $C D 8^{+}$effector T cells and Type I T cells (IFN- $\gamma$-producing) were also significantly reduced.
\end{abstract}

Conclusion: Alefacept causes a selective reduction in circulating effector memory $T$ cells (Tem) and relative preservation of central memory $\mathrm{T}$ cells $(\mathrm{Tcm})$ in psoriasis.

\section{Background}

A major pathogenic hypothesis for psoriasis vulgaris is that it is an inflammatory autoimmune disease initiated and sustained in skin regions through the actions of memory $\mathrm{CD} 4^{+}$and $\mathrm{CD} 8^{+} \mathrm{T}$ lymphocytes that serve as Type 1 effectors $[1,2]$. A significant expansion of Type $1 \mathrm{~T}$ cells in the peripheral circulation of psoriasis patients has been measured [3]. A number of biological therapies have been recently approved for use in psoriasis, such as Alefacept (lymphocyte function-associated antigen [LFA]-3 T cell inhibitory protein [TIP]; anti-CD2; Amevive; Biogen Idec), which is effective in approximately $30 \%$ of psoriasis patients $(75 \%$ clinical response from baseline) [4]. Understanding the effects and actions of such an agent is useful to evaluate the relative contribution of different cell types to the pathogenesis of psoriasis. 
CD2 is a costimulatory molecule found predominantly on lymphocytes and natural killer (NK) cells [5], but also on a small subset of dendritic cells (DCs) [6,7]. CD2 binding regulates the threshold of antigen to which $\mathrm{T}$ cells will react, increasing the affinity of the immune synapse, and it is important for effector actions of differentiated CD8 ${ }^{+}$ cytotoxic T lymphocytes [5,8]. CD2 ligation can deliver a stimulatory or inhibitory signal, or be involved in lymphocyte adhesion, depending on the system studied [912].

Alefacept is a fusion protein combining the first extracellular domain of LFA3 (CD58) with constant regions (CH2 and $\mathrm{CH} 3$ ) and the hinge domain of human IgG1. Alefacept has a number of effects in vitro including decreasing T cell alloreactivity and stimulating NK-mediated lysis of target cells. The proposed mechanism of action of alefacept is to bridge lymphocytes and NK cells by binding to CD2 and FCRIII, respectively $[4,13,14]$. Theoretically, this activates the NK cell to release its cytotoxic granules leading to lymphocyte apoptosis. However, these in vitro experiments used significantly higher doses of alefacept than were used in subsequent clinical trials, and also nonphysiological doses of NK: T cells, so it is difficult to establish their relevance to in vivo mechanisms of action.

Recently, several groups have further classified memory $\mathrm{T}$ cell subpopulations $\left(\mathrm{CD}_{45} \mathrm{RO}^{+}\right.$or $\left.\mathrm{CD}^{2} 5 \mathrm{RA}^{-}\right)$, describing cells by correlating surface phenotype and function $[15,16]$. Central memory T cells $(\mathrm{Tcm})$ are CCR7 ${ }^{+}$, express additional lymph-node homing receptors, lack immediate effector function, and differentiate into CCR7- cells on secondary stimulation. Effector memory $\mathrm{T}$ cells (Tem) are CCR7-, demonstrate receptors for inflamed tissue, and are capable of immediate effector function. Effector CD8+ $\mathrm{T}$ cells can be further defined as CD45RA+ CD27- and CD28[17]. These cells secrete interferon (IFN)- $\gamma$ and tumor necrosis factor (TNF)- $\alpha$, require exogenous cytokines for proliferation such as IL-2 and IL-15, and have cytolytic function.

We applied this more specific classification system to evaluate the relative $T$ cell reduction caused by alefacept treatment. Studies to date have shown that there is a dose dependant reduction in circulating $\mathrm{CD}^{+}$and $\mathrm{CD}^{+}$ $\mathrm{CD} 45 \mathrm{RO}^{+}$memory $\mathrm{T}$ cells [4], which remained reduced with a second course of alefacept [18]. We found that $\mathrm{CD}^{+}$and $\mathrm{CD}^{+}$effector memory T cells (Tem) (CCR7CD45RA-) were significantly decreased, with relatively less effect on central memory T cells (Tcm) $(\mathrm{CCR} 7+\mathrm{CD} 45 \mathrm{RA}-)$ and naïve $\mathrm{T}$ cells $\left(\mathrm{CCR} 7{ }^{+} \mathrm{CD} 45 \mathrm{RA}^{+}\right)$. There were also reductions in circulating $\mathrm{CD}^{+}$effector $\mathrm{T}$ cells (CCR7$\mathrm{CD}^{2} \mathrm{RA}^{+}$) and type $1 \mathrm{~T}$ cells (IFN- $\gamma$ producing T cells). The relative preservation of naïve and central memory $\mathrm{T}$ cells is an important finding of this study.

\section{Methods Study design}

Twenty-two patients with moderate to severe psoriasis (19 males, 3 females, ages 29-68 years, median 49 years) were enrolled in this study, which was approved by The Rockefeller University Hospital Institutional Review Board, and completed in 2003. Informed consent was obtained. This group of patients has been described previously [19]. Major inclusion criteria were: involvement of psoriasis vulgaris of $>10 \%$ body surface area, no treatment for at least 4 weeks prior to entering the study, no significant infections nor immunosuppression, and no significant renal, hepatic or other medical disease. Patients were treated with twelve $7.5 \mathrm{mg}$ weekly intravenous doses of alefacept, and the effect of this fusion protein on circulating T cells was studied by fluorescence-activated cell sorting (FACS). Two patients withdrew due to non-response and did not have final blood draws or biopsies.

\section{Peripheral blood and skin samples}

Peripheral blood draws were taken at 0, 1, 6 and 24 hours, and weeks 2, 4 and 13, before drug administration. Neutrophil, lymphocyte and monocyte counts were determined by routine complete blood count. Peripheral blood mononuclear cells (PBMCs) were isolated from heparinized samples using standard Ficoll-Hypaque (Pharmacia Biotech Inc., Piscataway, New Jersey) density gradient sedimentation. PBMCs were frozen in $10 \%$ dimethylsulfoxide (DMSO; ATCC, Manassas, Vermont) in RPMI-1640 (Gibco-BRL Life Technologies, Rockville, Maryland) with $1 \mathrm{mM}$ HEPES buffer (Sigma Aldrich, St. Louis, Missouri), 0.1\% gentamicin (Gibco-BRL Life Technologies) and 5\% normal human serum (C-Six Diagnostics, Germantown, Wisconsin), and stored at $-80^{\circ} \mathrm{C}$ until required. Skin punch biopsies were obtained at baseline (nonlesional and lesional), 2, 6 and 13 weeks (lesional). Tissue was frozen in OCT compound (Sakura Finetechnical, Tokyo, Japan) and stored at $-80^{\circ} \mathrm{C}$ for immunohistochemistry, and liquid nitrogen for RNA extraction.

Histologic response (remission) of psoriatic lesions was defined by normalization of keratin 16 expression (negative in normal epidermis) in week 13 biopsies and marked reduction in epidermal hyperplasia (quantified by computer- assisted image analysis) [19]. Change in epidermal thickness was calculated as a percentage by the following formula [(epidermal thickness at week 13 - epidermal thickness at week 0)/epidermal thickness at week 0] $\times$ 100. Other cases showed a range of outcomes that varied from some reduction in epidermal hyperplasia (but sustained keratin 16 expression) to no improvement in hyperplasia. These cases are termed "nonresponders". 


\section{Peripheral blood mononuclear cell phenotype}

PBMCs were stained for 15 minutes at room temperature with the following antibodies (5 $\mu \mathrm{l} / 10^{5}$ cells): CD2, CD19, CD45RA (fluorescein isothiocyanate, FITC), CD8, CD16, CD27, CD45RO, CD49d, CD56 (phycoerythrin, $\mathrm{PE}), \mathrm{CD} 3, \mathrm{CD} 4, \mathrm{CD} 8$ (peridinin-chlorophyll-protein, PerCP), CD3, CD45RO (allophycocyanin, APC) (Becton Dickinson), CD11a (FITC) (Immunotech, Westbrook, Maine), CD103 (FITC) (Biodesign International), cutaneous lymphocyte antigen (CLA/HECA) (FITC) (BD Pharmingen), LFA-3TIP (PE) (BD Pharmingen, custom design), CCR7 (PE) (R \& D System, Minnesota). Appropriate IgG isotype controls were also used (Becton Dickinson). Cells were washed with FACSwash $[0.1 \%$ sodium azide (Sigma Aldrich), 2\% fetal calf serum (Gibco-BRL Life Technologies) in phosphate buffered saline] and resuspended in 1.3\% formaldehyde (Fisher Scientific) in FACSwash. Samples were analyzed within 24 hours with four color staining using a FACSCalibur Flow Cytometer and CELLQuest software after calibration with CaliBRITE beads and FacsComp sotware (Becton Dickinson).

\section{Whole blood intracellular cytokine staining}

Heparinized whole blood was activated for 4 hours using $25 \mathrm{ng} / \mathrm{ml}$ phorbol myristate acetate (PMA) and $2 \mu \mathrm{g} / \mathrm{ml}$ ionomycin, in the presence of $10 \mu \mathrm{g} / \mathrm{ml}$ brefeldin A (Sigma Aldrich Corp, St. Louis). Ethylenediaminetetraacetic acid was added ( $2 \mathrm{mM}$, Fisher). Red blood cells were lysed using FACS Lysing solution (Becton Dickinson), cells were washed and frozen in the media described above (10\% DMSO, 5\% PHS in RPMI). Unactivated control cells were included in the assays. Prior to cytokine staining, cells were thawed, washed and permeabilized using FACS Permeabilizing solution (Becton Dickinson). FACS analysis was performed using antibodies specific for intracellular IFN- $\gamma$, IL-2 (FITC), TNF- $\alpha$, IL-4 (PE) (Becton Dickinson) and IL-10 (PE) (BD Pharmingen).

\section{T cell activation (CD69 expression)}

PBMCs were activated in vitro using $1 \mu \mathrm{g} / \mathrm{ml}$ OKT3 (antiCD3) (Ortho Biotech, Toronto, Canada) or $1 \mu \mathrm{g} / \mathrm{ml} \mathrm{T1} 1.1$ and T11.2 (anti-CD2) (Immunotech) for 4 hours. Early T cell (CD3-FITC) activation was measured by surface expression of CD69 (FITC). Samples were analyzed by FACS as described for PBMC phenotype.

\section{Statistics}

Data were transformed into logarithmic data due to the biological variability of the data and to accommodate outliers, and so averages are presented as geometric means. Change at week 13 was compared to baseline using a 2tailed, paired student's t test; significance was accepted as $\mathrm{P}<0.05$.

\section{Results \\ Analysis of histologic response of psoriasis to alefacept administration}

The patients demonstrated better than expected clinical response rates, with $45 \%$ (10/22) of patients achieving an improvement of Psoriasis Activity and Severity Index (PASI) greater than $70 \%$, with a mean overall reduction in PASI of 50\%. After alefacept administration, 55\% (12 of 22) of patients were judged to have disease remission by histologic criteria (outlined in materials and methods), and are termed "responders". The other 10 patients were termed "non-responders".

\section{Alefacept preferentially decreases circulating memory $T$ cell subsets}

There is a dramatic reduction of peripheral lymphocytes (38\% reduction) and monocytes (58\% reduction) during the first hour of Alefacept administration, with quick recovery within days [20]. Monocytes returned to baseline levels, but lymphocyte counts were reduced by $23 \%$ over the subsequent 12 weeks. Table 1 lists the changes in various populations of circulating lymphocytes after 12 weeks of alefacept administration. T cells were the main population of lymphocytes that showed a decrease in absolute cell number, whereas only slight changes were seen in B cells and NK cells.

A variety of different leukocyte markers were used to quantify naïve $\mathrm{T}$ cell populations and memory $\mathrm{T}$ cell populations, including specific populations of memory T cells specialized for homing to skin/epithelium and inflammatory sites (Table 1 ). Naïve populations of CD4+ and CD8+ $\mathrm{T}$ cells were affected to a comparatively small extent by alefacept, whereas memory populations were mainly targeted by this agent. For example, memory CD4+ $\mathrm{T}$ cells were decreased by a mean of $40 \%$, and CD $8^{+}$memory cells were decreased by a mean of $65 \%$. T cells that were differentiated for skin homing $\left(\mathrm{CLA}^{+}\right)$, epithelial homing $\left(\mathrm{CD}_{103^{+}}\right)$or for binding to vascular cell adhesion molecule-1 or intercellular adhesion molecule-1 (CD49d hi and LFA- 1 hi, respectively) were strongly affected by alefacept in the peripheral circulation. These observations suggest that cell populations which differentiate for homing to peripheral tissues (effector memory $\mathrm{T}$ cells) might be selectively targeted by alefacept in psoriasis patients. While circulating $\mathrm{CD}^{+}$and $\mathrm{CD}^{+}$memory cells were reduced in all patients, there was some correlation between $\mathrm{CD}^{+}$and $\mathrm{CD}^{+} \mathrm{Tcm}$ lymphocyte subpopulations and change in PASI $(\mathrm{R}=0.54$, and $\mathrm{R}=0.47$, respectively).

\section{Alefacept selectively targets circulating effector memory $T$ cells (Tem)}

Memory populations of $\mathrm{CD}^{+}$and $\mathrm{CD}^{+} \mathrm{T}$ lymphocytes can be divided into $\mathrm{T}$ cell populations that home mainly 
Table I: Phenotypic analysis of peripheral blood mononuclear cells during treatment with Alefacept.

\begin{tabular}{|c|c|c|c|c|c|c|c|c|}
\hline Cell type & Phenotypic marker & Do & Wk 13 & $\begin{array}{l}\text { Percent } \\
\text { change }\end{array}$ & $P$ value & & & \\
\hline $\mathrm{T}$ cell & $\mathrm{CD}^{+}{ }^{+}$ & 1474 & 967 & -34.0 & $<10^{-4}$ & & & \\
\hline Memory T cell & $\mathrm{CD}^{+}{ }^{+} \mathrm{CD}_{45 \mathrm{RA}^{-}}$ & 900 & 467 & -48.0 & $<10^{-4}$ & & & \\
\hline B cell & $\mathrm{CD} / 9^{+}$ & 211 & 198 & -6.0 & 0.65 & & & \\
\hline NK cell & $\mathrm{CD} 56^{+} \mathrm{CD} 16^{+} \mathrm{CD} 3-$ & 125 & 130 & 4.0 & 0.78 & & & \\
\hline Naïve CD4+ & $\mathrm{CD}^{+}{ }^{+} \mathrm{CD} 45 \mathrm{RA}^{+}$ & 247 & 236 & -5.0 & 0.60 & & & \\
\hline Memory $\mathrm{CD}^{+}$ & $\mathrm{CD}^{+}{ }^{+} \mathrm{CD} 45 \mathrm{RO}^{+}$ & 484 & 290 & -40.0 & 0.0005 & & & \\
\hline Naïve CD8 ${ }^{+}$ & $\mathrm{CD}^{+} \mathrm{CD}^{2} 7^{+} \mathrm{CD} 45 \mathrm{RA}^{+}$ & 166 & 135 & -19.0 & 0.025 & & & \\
\hline Memory CD8 ${ }^{+}$ & $\mathrm{CD}^{+} \mathrm{CD}^{-} 7^{+} \mathrm{CD} 45 \mathrm{RA}^{-}$ & 164 & 57 & -65.0 & $<10^{-4}$ & & & \\
\hline Effector CD8 ${ }^{+}$ & $\mathrm{CD}^{+}{ }^{\mathrm{C}} \mathrm{CD} 27-\mathrm{CD}^{-} 4 \mathrm{RA}^{+}$ & 21 & 14 & -32.0 & 0.015 & & & \\
\hline $\mathrm{CD}^{+}{ }^{+} \mathrm{CD} 25^{+} \mathrm{T}$ cells & $\mathrm{CD}^{+}{ }^{+} \mathrm{CD} 25^{+}$ & 525 & 365 & -30.0 & 0.0124 & & & \\
\hline Skin-homing CD4+ ${ }^{+}$ & $\mathrm{CD}^{+} \mathrm{CLA}^{+}$ & 86 & 44 & -49.0 & 0.0012 & & & \\
\hline Skin-homing CD8 ${ }^{+}$ & $\mathrm{CD}^{+} \mathrm{CLA}^{+}$ & 23 & 12 & -48.0 & 0.009 & & & \\
\hline Epithelial-homing CD8 ${ }^{+}$ & $\mathrm{CD}^{+} \mathrm{CDIO3}^{+}$ & 17 & 5 & -70.0 & $<10^{-4}$ & & & \\
\hline VLA-4lo & CD8+CD49dlo & 172 & 132 & -23.0 & 0.002 & & & \\
\hline VLA-4hi & CD8 ${ }^{+}$CD49dhi & 226 & 97 & -57.0 & $<10^{-4}$ & & & \\
\hline LFA- Ilo & $\mathrm{CD}^{+} \mathrm{CD} / \mathrm{l} \mathrm{a}^{\mathrm{lo}}$ & 201 & 155 & -23.0 & 0.018 & & & \\
\hline LFA-I hi & $\mathrm{CD} 8^{+} \mathrm{CD} / \mathrm{la} \mathrm{a}^{\mathrm{hi}}$ & 202 & 80 & -61.0 & $<10^{-4}$ & & & \\
\hline Memory $\mathrm{T}$ cell subsets & Phenotypic marker & Do & Wk 13 & $\begin{array}{l}\text { Percent } \\
\text { change }\end{array}$ & P value & CD2 MFI D0 & CD2 MFI Wk I3 & $P$ value \\
\hline Naïve $\mathrm{CD}^{+}$ & $\mathrm{CD}^{+}{ }^{\mathrm{CCR}} 7^{+} \mathrm{CD} 45 \mathrm{RA}^{+}$ & 216 & 220 & 2.0 & 0.88 & 90 & 88 & 0.49 \\
\hline $\mathrm{Tcm} \mathrm{CD4}^{+}$ & $\mathrm{CD}^{+}{ }^{+} \mathrm{CCR} 7^{+} \mathrm{CD} 45 \mathrm{RA}^{-}$ & 377 & 274 & -27.0 & 0.0135 & 141 & 119 & 0.0002 \\
\hline $\mathrm{Tem} \mathrm{CD4}^{+}$ & $\mathrm{CD}^{+}{ }^{+} \mathrm{CCR} 7-\mathrm{CD} 45 \mathrm{RA}-$ & 179 & 67 & -63.0 & $<10^{-4}$ & 198 & 146 & $<10^{-4}$ \\
\hline Naïve $\mathrm{CD}^{+}{ }^{+}$ & $\mathrm{CD}^{+} \mathrm{CCR7}^{+} \mathrm{CD} 45 \mathrm{RA}^{+}$ & 75 & 78 & 4.0 & 0.76 & 127 & 120 & 0.20 \\
\hline $\mathrm{Tcm} \mathrm{CD8}^{+}$ & $\mathrm{CD}^{+}{ }^{+} \mathrm{CCR} 7^{+} \mathrm{CD}^{-} 5 \mathrm{RA}^{-}$ & 48 & 25 & -47.0 & $<10^{-4}$ & 192 & 159 & 0.003 \\
\hline Tem CD8 ${ }^{+}$ & $\mathrm{CD}^{+}{ }^{\mathrm{C} C R 7} 7^{-}$CD45RA- & 110 & 40 & -63.0 & $<10^{-4}$ & 233 & 190 & 0.002 \\
\hline Effector CD8 ${ }^{+}$ & $\mathrm{CD}^{+}{ }^{-} \mathrm{CCR} 7-\mathrm{CD}^{-}$RRA $^{+}$ & 102 & 51 & -50.0 & 0.0001 & 178 & $|3|$ & 0.0002 \\
\hline
\end{tabular}

Geometric mean absolute cell number per $\mu \mathrm{l}$ circulating blood at baseline (D0, day 0 ) and post treatment (week I3). Percent change is calculated by [(week I3-week 0)/week 0 as a \%]. CD2 mean fluorescence intensity (MFI) of memory cell subsets. P value comparing week 0 and week 13 .

to lymph nodes, central memory $\mathrm{T}$ cells $(\mathrm{Tcm})$, versus effector memory $\mathrm{T}$ cells (Tem), which home mainly to peripheral or inflammatory sites. The expression of CCR7 and CD45RA was used to classify CD4+ $4^{+} \mathrm{CD} 8^{+} \mathrm{T}$ cells as naïve $\left(\mathrm{CCR} 7+{ }^{+} \mathrm{CD} 45 \mathrm{RA}^{+}\right)$, Tcm $(\mathrm{CCR} 7+\mathrm{CD} 45 \mathrm{RA})$ or Tem (CCR7- CD45RA-) [15]. In CD4+ $\mathrm{T}$ cells, the Tem population was consistently affected to a much larger extent than the $\mathrm{Tcm}$ population (Table 1) (mean reductions compared to baseline of $63 \%, \mathrm{p}<10^{-4}$ versus $27 \%$, not significant). Similarly, Tem cells in the $\mathrm{CD} 8^{+}$population were affected more than Tcm cells (mean reductions of $63 \%$, versus $47 \%$, both $\mathrm{p}<10^{-4}$ ). At week 13 , the difference in $\mathrm{CD} 4{ }^{+} \mathrm{Tcm}$ versus Tem, as well as CD8+ Tcm versus Tem was also significant, $\left(\mathrm{P}<10^{-4} ; 0.005\right.$ respectively $)$.

\section{Alefacept selectively reduces circulating Type I T cells}

Because there is an increase in circulating Type $1 \mathrm{~T}$ cells in psoriasis patients [3], we measured the effect of alefacept on circulating populations of Type 1 (IFN- $\gamma$-producing) and Type 2 (IL-4-producing) T cells by flow cytometry (Fig. 1). Ninety percent of T cells at baseline and week 13 could be successfully activated by PMA and inonmycin, as judged by induction of CD69 (data not shown). Type $1 \mathrm{~T}$ cells were consistently reduced after alefacept administration (mean reduction $59 \%, \mathrm{p}<0.0001$ ). Consistent reductions in TNF- $\alpha$-producing and IL-2 producing T cell subsets were also measured, but the overall effect was smaller than on IFN- $\gamma$-producing T cells. There was much less intracellular cytokine expression in the Type 2 cytokines IL-4 and IL-10, so interpretation is less meaningful. There was a $2 \%$ mean reduction for IL- $4(\mathrm{p}=0.94)$ and $32.9 \%$ mean reduction of IL-10 $(p=0.03)$.

\section{Alefacept does not affect expression of CD69 after activation of PBMCs}

In vitro activation of PBMCs with OKT3 and anti-CD2 monoclonal antibodies T11.1 and T11.2 showed no statistically significant difference in activation as measured by surface CD69 expression at week 13 compared to baseline (Fig. 2).

\section{Alefacept binding parallels CD2 expression on memory $T$ cell populations}

Table 1 shows average mean fluorescence intensity (MFI) values for CD2 expression in naïve, Tcm and Tem populations, as determined from combined measures in all 


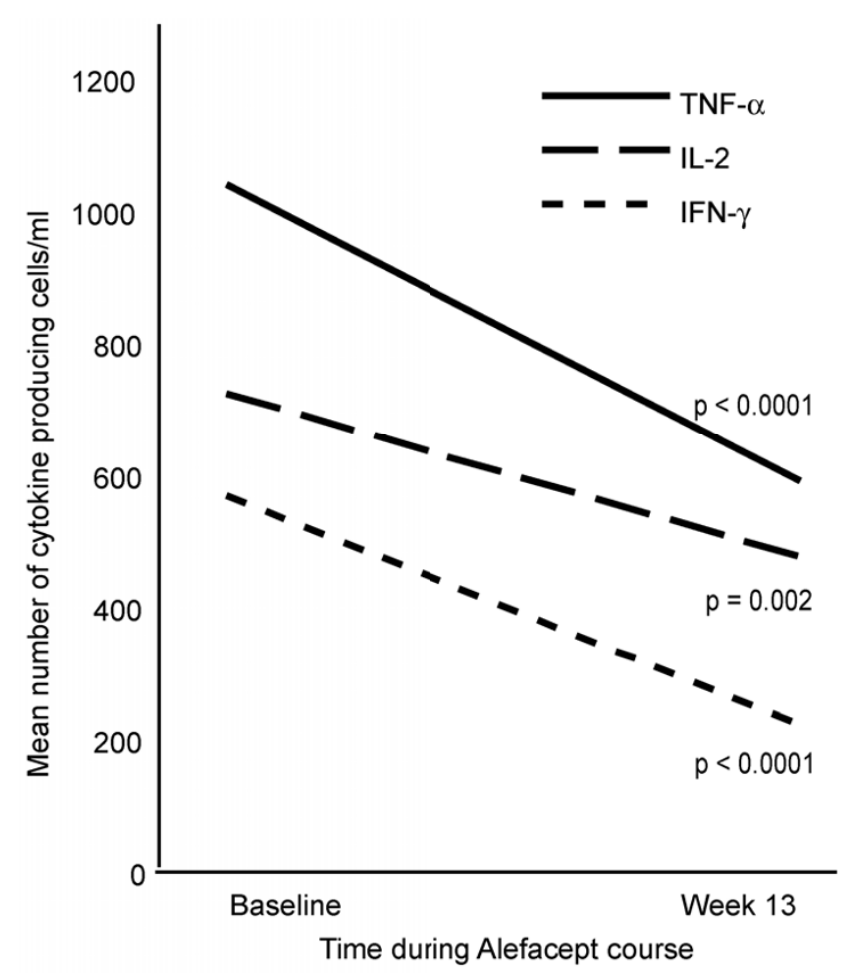

Figure I

Type I T cells (IFN- $\gamma$ producing) are decreased with alefacept therapy. Intracellular cytokine FACS detection of mean number of TNF- $\alpha$, IL-2 and IFN- $\gamma$ cells $/ \mathrm{ml}$, which are significantly decreased with therapy, $\mathrm{P}$ value indicated.

patients in the study. Tem populations tend to have higher expression of CD2 compared to Tcm populations and that slight (but statistically significant) reductions in average CD2 MFI values were measured on memory cell populations after alefacept administration. In overall terms, levels of CD2 expression strongly parallels reductions in the respective cell populations in the peripheral circulation after alefacept administration. This difference, in turn, may be produced by quantitative differences in alefacept binding to T cells.

\section{Discussion}

Alefacept is the first therapeutic agent targeted to T lymphocytes that has been shown to have a selective effect on effector memory $\mathrm{T}$ cells (Tem) versus central memory $\mathrm{T}$ cells (Tcm) in humans. Our results suggest that differential effects of alefacept on naïve versus Tcm and Tem T cell pools relates to increased CD2 expression on effector T cells (Table 1) and thus differential binding of alefacept to surface CD2 molecules. The decreases in circulating populations that are differentiated as Type 1 effectors (LFA-

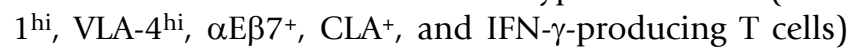

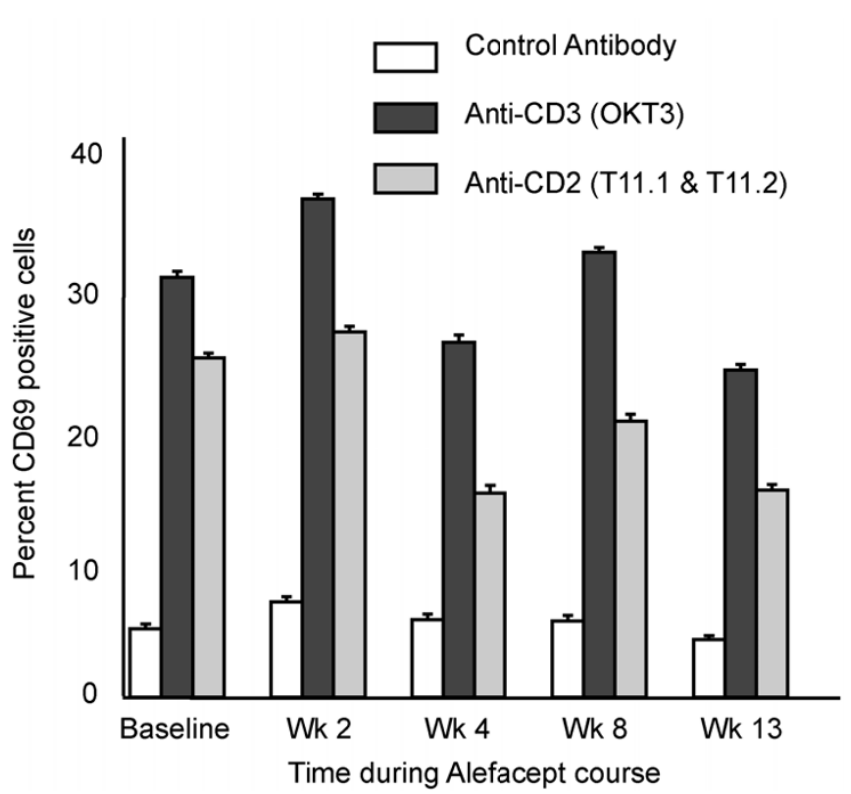

Figure 2

$\mathbf{T}$ cells can still be activated during treatment with Alefacept. Percent CD69 positive cells following in vitro activation with control, anti-CD3 (OKT3) or anti-CD2 (TII.I and TII.2). Comparison of CD69 expression on T cells activated with either OKT3 or TII.I and TII.2 at baseline and week I3. No significant differences. Geometric mean data, standard error of the mean.

argue for roles of these $\mathrm{T}$ cell subsets in disease pathogenesis, and indeed these $\mathrm{T}$ cell subsets are concentrated in skin lesions. Peripheral Type 1 deviation previously observed in psoriasis [3] seems to be largely corrected through alefacept administration, as Type $1 \mathrm{~T}$ cells are significantly reduced at week 13, but Type 2 (IL-4 producing) T cells are comparatively unaffected (Fig. 1).

An encouraging finding of this study is that central memory T cells ( $\mathrm{Tcm}$ ) and naïve T cells are relatively preserved. This may be beneficial as there is realistic concern about toxicity caused by $\mathrm{T}$ cell-targeted immunosuppressives, particularly in the ability to sustain immunologic memory and to mount immune responses to new pathogens. Recall responses to intradermal antigens are preserved, as are antibody responses to a neoantigen (phiX174) [21]. Although it is not yet clear which cells are actually most important for maintaining immunological memory, it is logical that maintenance of the naïve and central memory populations should leave primary and recall responses intact. Also, the changes in lymphocyte population with Alefacept are opposite to those occurring in aging individuals (immune senescence) where naïve $\mathrm{T}$ cells are decreased and memory populations are increased [22]. 
Although there is a consistent reduction in circulating memory T cells in all patients, it is puzzling that there is not a better correlation between clinical response and circulating memory cell reductions; that is, everyone has a relative reduction in T cells, but not everyone gets better. The correlation coefficients for change in PASI and memory CD4 $\left(\mathrm{CD}^{2} 5 \mathrm{RO}^{+}\right)$and $\mathrm{CD}^{+}{ }^{+} \mathrm{T}$ cells $(\mathrm{CD} 45 \mathrm{RA}-)$ are similar to previously reported studies [4]. It is likely for clinical and histological response, changes at the tissue level are more important than those in the circulation. In lesional psoriatic tissue, response to alefacept therapy correlates extremely well with reductions in infiltrating lymphocytes $(r=0.9)$, lesional DCs and inflammatory genes [19].

CD2 targeted therapeutics have been successful at delaying rejection of allogeneic organ transplants in model systems, but have been less successful at reversing ongoing rejection reactions [23] and, generally, effects of these agents to decrease $\mathrm{T}$ cell antigen reactivity is restricted to the period of initial antigen exposure. It is interesting that Alefacept is effective in certain psoriasis patients, which is an established reaction. We examined the ability of $\mathrm{T}$ cells to be activated before and after alefacept administration through CD3 antibodies or by use of mitogenic CD2 antibody combinations. While slight decreases in T cell activation were seen at week 13 after CD3 and CD2 ligation, cells remained quite activatable, which is distinctly different from previous in vitro studies which observed anergic effects of alefacept [9].

Thus, the mechanism of $\mathrm{T}$ cell reductions remains to be established. Possible mechanisms of action include the previously proposed bridging effect between $\mathrm{T}$ cells and NK cells leading to direct lymphocyte cell death. While we have not found any evidence of apoptosis in the circulation (data not shown), this may be occurring slowly at least at the tissue level. Secondly, alefacept may preferentially bind to lesional $\mathrm{T}$ cells, resulting in a disruption of the organization of $\mathrm{T}$ cells and DCs in the tissue [2]. Thirdly, binding of alefacept to lymphocyte CD2 may result in sequestration of the bound cell from the circulation into lymphoid organs, and subsequent depletion. A fourth possibility is that there is a relative increase in tissue regulatory $\mathrm{T}$ cells.

\section{Conclusion}

This study is a detailed analysis of the effects of alefacept on the circulating subpopulations of lymphocytes, and the relative preservation of the naïve and central memory $\mathrm{T}$ cells is an important finding. There are also reductions in the putative pathogenic populations in psoriasis, Tem and type $1 \mathrm{~T}$ cells.

\section{Abbreviations}

Tem effector memory T cells

Tcm central memory T cells

LFA lymphocyte function-associated antigen

TIP T cell inhibitory protein

NK natural killer

DCs dendritic cells

IFN interferon

TNF tumor necrosis factor

FACS fluorescence-activated cell sorting

PBMCs peripheral blood mononuclear cells

DMSO dimethylsulfoxide

FITC fluorescein isothiocyanate

PE phycoerythrin

PerCP peridinin-chlorophyll-protein

APC allophycocyanin

PMA phorbol myristate acetate

MFI mean fluorescence intensity

PASI Psoriasis Activity and Severity Index

CLA cutaneous lymphocyte antigen

\section{Competing interests}

The author(s) declare that they have no competing interests.

\section{Authors' contributions}

JGK conceived of the study. EL, PG, MS-W, JGK, cared for the patients in the clinical trial. FC, S-LL, TK, IC, AK, IN performed research and analysis. KMW, FC, MAL performed statistical analysis. FC, JGK, MAL analysed and interpreted data, and wrote the manuscript. All authors read and approved the final manuscript.

\section{Acknowledgements}

JGK is supported by the following National Institutes of Health (NIH) grants; a Center for Clinical and Translational Science Award (UL I

RR024 I 43), and NIH grants ROI Al-49572 and Al-49832. MAL is the recip- 
ient of NIH/NIAMS grant I K23 AR052404-0IAI. Written consent was obtained from the patient or their relative for publication of study.

\section{References}

I. Krueger JG: The immunologic basis for the treatment of psoriasis with new biologic agents. J Am Acad Dermatol 2002, 46: $1-23$.

2. Lew W, Bowcock AM, Krueger JG: Psoriasis vulgaris: cutaneous lymphoid tissue supports T-cell activation and 'Type I' inflammatory gene expression. Trends Immunol 2004, 25(6):295-305.

3. Austin LM, Ozawa M, Kikuchi T, Walters IB, Krueger JG: The majority of epidermal $\mathbf{T}$ cells in Psoriasis vulgaris lesions can produce type I cytokines, interferon-gamma, interleukin-2, and tumor necrosis factor-alpha, defining TCI (cytotoxic T lymphocyte) and THI effector populations: a type I differentiation bias is also measured in circulating blood $\mathbf{T}$ cells in psoriatic patients. J Invest Dermatol 1999, I I 3:752-759.

4. Ellis CN, Krueger GG: Treatment of chronic plaque psoriasis by selective targeting of memory effector T lymphocytes. New England Journal of Medicine 200I, 345(4):248-255.

5. Dustin ML, Springer TA: Role of lymphoctye adhesion receptors in transient interactions and cell locomotion. Annual Review of Immunology 1991, 9:27-66.

6. Crawford K, Gabuzda D, Pantazopoulos V, Xu J, Clement C, Reinherz E, Alper CA: Circulating CD2+ monocytes are dendritic cells. J Immunol 1999, 163:5920-5928.

7. Di Pucchio T, Lapenta C, Santini SM, Logozzi M, Parlato S, Belardelli F: CD2+/CDI4+ monocytes rapidly differentiate into CD83+ dendritic cells. Eur J Immunol 2003, 33:358-367.

8. Bacchmann MF: CD2 sets quantitative thresholds in T cell activation. Journal of Immunology 1999, 190:1383-1391.

9. Miller GT, Hochman PS, Meier W, Tizard R, Bixler SA, Rosa MD, Wallner BP: Specific interaction of lymphocyte function associated antigen 3 with CD2 can inhibit T cell responses. Journal of Experimental Medicine 1993, I 78:211-222.

10. Lattine D, De La Parra B, Nizet Y, Cornet A, Giovino-Barry V, Monroy $R$, White-Schart ME, Bazin $H$ : An-anti-CD2 mAb induces immunosuppresssion and hyporesponsiveness of CD2+ human $\mathbf{T}$ cells in vitro. International Immunology 1995, 8:1113-1119.

II. Dumont C, Deas O, Mollereau B, Hebib C, Giovino-Barry V, Bernard A, Hirsch F, Charpentier B, Senik A: Potent apoptotic signaling and subsequent unresponsiveness induced by a sigle CD2 mAb (BTI-332) in activated human peripheral T cells. Journal of Immunology 1998, 1 60:3797-3804.

12. van Kooyk Y, van de Weil-van Kemenade P, Weder P, Kuijers TW, Figdor CG: Enhancement of LFA-I-mediated cell adhesion by triggering through CD2 or CD3 on T lymphocytes. Nature 1989, 342:811-812.

13. Majeau GR, Meier W, Jimmo B, Kioussis D, Hochman PS: Mechanisms of lymphocyte function-associated molecule 3-Ig fusion proteins inhibition of $\mathbf{T}$ cell responses. Structurel Function analysis in vitro and in human CD2 transgenic mice. Journal of Immunology 1994, I 52:2753-2767.

14. da Silva AJ, Brickelmaier M, Majeau GR, Li Z, Su L, Hsu Y-M, Hochman PS: Alefacept, and immunomodulatory recombinant LFA-3/ IgG I fusion protein, induces CD I 6 signaling and CD2/CD I 6dependant apoptosis of CD2+ cells. Journal of Immunology 2002, | 68:4462-447|.

15. Sallusto F, Lenig D, RForster R, Lipp M, Lanzavecchia A: Two subsets of memory $T$ lymphocytes with distinct homing potentials and effector functions. Nature 1999, 40 I:708-7I2.

16. Sallusto F, Geginat J, Lanzavecchia A: Central memory and effector memory $T$ cell subsets: function, generation, and maintenance. Annu Rev Immunol 2004, 22:745-763.

17. Hamann D, Baars PA, Rep MHG, Hooibrink B, JKertof-Garde SR, Klein MR, van Lier RAW: Phenotypic and functional separation of memory and effector human CD8+ T cells. Journal of Experimental Medicine 1997, I 86(9): I707-I4I8.

18. Gordon KB, Vaishnaw AK, O'Gorman J, Haney J, Menter A: Treatment of psoriasis with alefacept: correlation of clinical improvement with reductions of memory T-cell counts. Arch Dermatol 2003, I39( I 2): I563-I570.
19. Chamian F, Lowes MA, Lin SL, Lee E, Kikuchi T, Gilleaudeau P, Sullivan-Whalen M, Cardinale I, Khatcherian A, Novitskaya I, Wittkowski KM, Krueger JG: Alefacept reduces infiltrating $T$ cells, activated dendritic cells, and inflammatory genes in psoriasis vulgaris. Proc Natl Acad Sci U S A 2005, I 02(6):2075-2080.

20. Haider AS, Lowes MA, Gardner H, Bandaru R, Darabi K, Chamian F, Kikuchi T, Gilleaudeau P, Sullivan-Whalen M, Cardinale I, Novitskaya I, Krueger JG: Novel insight into agonistic mechanism of alefacept in vivo: Differentially expressed genes may serve as biomarkers of response in psoriasis patients. J Immunol 2007, I 78( I I):7442-9.

21. Gottlieb AB, Casale TB, Frankel E, Goffe B, Lowe N, Ochs HD, Roberts JL, Washenik K, Vaishnaw AK, Gordon KB: CD4+ T-celldirected antibody responses are maintained in patients with psoriasis receiving alefacept: results of a randomized study. J Am Acad Dermatol 2003, 49(5):816-825.

22. Grubeck-Loebenstein B, Wick G: The aging of the immune system. Adv Immunol 2002, 80:243-284.

23. Chavin KD, Lau HT, Bromberg JS: Prolongation of allograft and xenograft survival in mice by anti-CD2 monoclonal antibodies. Transplantation 1992, 54:286-291.
Publish with Bio Med Central and every scientist can read your work free of charge

"BioMed Central will be the most significant development for disseminating the results of biomedical research in our lifetime. "

Sir Paul Nurse, Cancer Research UK

Your research papers will be:

- available free of charge to the entire biomedical community

- peer reviewed and published immediately upon acceptance

- cited in PubMed and archived on PubMed Central

- yours - you keep the copyright

Submit your manuscript here:

http://www.biomedcentral.com/info/publishing_adv.asp
BioMedcentral 